\title{
Compensation Strategies Used by EFL Learners in Speaking and Listening Skills
}

https://doi.org/10.32792/utq/utj/vol11/1/4

Shehla Mohsin Abdul Sahib

University of Thi-Qar

College of Mass Media

\section{أساليب الإثابة المستخدمة من قبل متعلمي اللغة الانكليزية في مهارات التحدث والإصغاء}

تهذف هذه الدراسة إلى إعطاء نظرة تجريية لأساليب الطلاب للإثابة عن مقاطع المعلومات المفقودة في مهارات التحدث و الإصغاء وذللك من خلال أجراء مقابلة امتحان شفهي ـ أساليب الإثابة الملحوظة الموظفة مسبقا والتي لم يتم توظيفها في هذا البحث تم تدوينها ـ بالإضافة إلى ذلك فان اساليب الاثابة يتم ترتيبها ابتداء من الاكثر استخداما الى الاقل استخداما من قبل

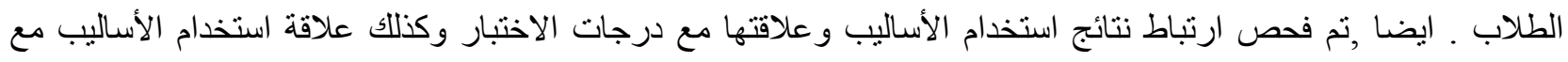
الجنس و عامل العمر. لوحظ أن هنالك علاقة بين أساليب التخمين و الجنس الأنثوي , كذللك بين أساليب التخمين و الطلاب الأكبر

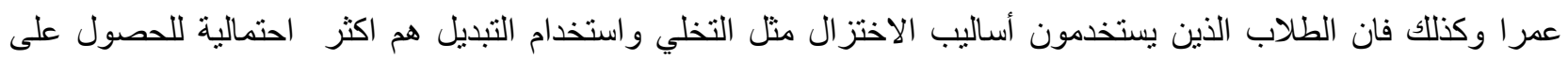
درجات واطئة في الامتحان , الثيء الذي يقترح أهمية تعليمهم بدائل لهذه الأساليب

\begin{abstract}
This study aims to provide an empirical foundation for the students strategies to compensate for missing knowledge in listening and speaking skills during undertaking an oral exam interview. Observable compensation strategies that were employed and not employed in this paper written. In addition, strategies are ranked in order of most utilized to least utilized by study participants. Further correlation results of strategies to test score and strategies to the sex and age variables are examined. Relationships were observed between guessing strategies and female students, as well as guessing strategies and older students. Also students who engaged in reduction strategies such as giving up and replacement were most likely to have lower test scores, suggesting the importance of teaching them alternations to these strategies.
\end{abstract}

Key words: compensation strategies, learning strategies, communication strategies, guessing. 


\section{University of Thi-Qar Journal Vol.11 No.1 Mar 2016 \\ Web Site: https://jutq.utq.edu.iq/index.php/main Email: journal@jutq.utq.edu.iq}

\section{1- The Problem}

There is an apparent reticence on the parts of learners to use compensation strategies. They have fossilized study habits and learning expectations that may be obstacles to language learning. Language instructors do not concentrate their attention on the eradication of such habits. Students have been provided with class activities in which compensation strategies need to be activated. They must develop learning strategies conducive to foreign language learning. Brown (1994:96) considers "strategies investment, the learner's own personal commitment of time, effort, and attention " critical for the success of language learning and urges teachers to seize every opportunity to help learners develop and use strategies that will transform them into independent learners, capable of taking responsibility for their own learning.

\section{2-Objectives}

This study has three aims they are :-

- Identifying compensation strategies used by the students .

- Identifying strategies typically not utilized by the students .

- Exploring possible relationships between the use of compensation strategies, test scores, and student sex and age

\section{3- Definitions}

Oxford (1990:47) defines compensation strategies as those that :

Enable learners to use the new language for either comprehension or production despite limitation in Knowledge. Compensation strategies are intended to make up for an inadequate repertoire of grammar and, especially, of vocabulary.

Oxford (1990:49) offers 10 compensation strategies: guessing by linguistic clues, guessing by other clues, switching to the mother tongue, getting help, using mime or gesture, avoiding communication partially or totally, selecting the topic, adjusting or approximating the message, coining word, and using circumlocution or synonymy .

It is noticed that students avoid communication altogether or panicking and giving up two "strategies "or" reactions " that are not very effective for learning or maintaining communication. Windle (2000: 91) writes that such a strategy may arise because of cultural reasons and serve to help the student " save face " for both the student and teacher. Nevertheless, whether culturally motivated or not, giving up or turning out often creates an uncomfortable atmosphere that can obstruct further conversation practice ,and during exams, negatively impact the student's score. Teaching students positive strategies to communication on idea with limited vocabulary and 


\section{University of Thi-Qar Journal Vol.11 No.1 Mar 2016 \\ Web Site: https://jutq.utq.edu.iq/index.php/main Email: journal@jutq.utq.edu.iq}

grammar will likely improve test scores, increase conversation practice, and help students become more communicatively confident and competent.

Moreover, Gardner (1985:18) suggests that maintaining or increasing the student motivation is one of the challenges that teachers face where can improve language learning. Abdesslem (1996 : 91 ) argues that highly motivated students become wary of classrooms that tend to focus too much on form instead of enabling them to interact in the target language. In addition, students without high motivation can become motivated through successful experiences interacting in the target language. Thus, teaching students compensation strategies can increase motivation and improve students potential for success in learning. Furthermore, Kim \& Margolis (2000:60-68) see that effective deployment can enrich the student experience of meaningful communication, thereby boosting self -confidence and self-efficacy. Compensation strategies are important skills to teach, as well as for effective communication ability in the target language.

Oxford (1990:80) developed her view of compensation strategies within the framework of language learning strategies that aim to teach skills to help students become autonomous learners. She conceptualized learning strategies into two categories, direct and indirect. The direct strategies include memory, cognitive, and compensation. The indirect strategies include metacognitive, affective strategies and social strategies. Margolis \& Kim (2000:25) reported that English classrooms tend to overemphasize memory, and neglect the other 5 types. It seems a safe assumption that by diversifying student awareness and ability in all the learning strategies, their learning efficiency may increase.

This study focuses on compensation strategies. Oxford term " compensation strategies " and its definition are by no means agreed upon or accepted in the literature. In fact, few writers use that term. The most commonly found terminology is "communication strategies ". Khanji ( 1996 : 41 ) reported that the seminal work on this topic was based on error analysis research, focusing on identifying mistakes the students made in communication. As functional approaches came to replace structural studies, discourse analysis became the focus (Khanji 1996:60). From this approach, communication strategies became defined as "problem activity, which arises from the disparity between the learner's ends and means" (Abdesslem,1996:60).

Khanji (1996:52) identified three components of the communication strategies 1- a communication difficulty owing to target language inadequacy. 2- student awareness of the problem, and 3- a solution to overcome it. Faerch and Kasper (1983:22) considered the communication strategy as an attempt to solve a problem while trying to achieve a language goal, but regarded student consciousness of the strategy as only potential .In other words ,students are not always conscious of their strategies utilization. Brown( 1994: 31) expanded the definition further by including verbal and non-verbal mechanism for solving the communication problem. Abdesslem (1996:23), however, in pursuing a similar way to Brown, regarded the term " communication strategies " as problematic because many of the instances of their use in the literature could be attributed to insufficient awareness of discourse strategies -such as opening and closing topics, language gambits and the like. He, therefore, argued that " communication 


\section{University of Thi-Qar Journal Vol.11 No.1 Mar 2016 \\ Web Site: https://jutq.utq.edu.iq/index.php/main Email: journal@jutq.utq.edu.iq}

strategies " become a suspect label and that routines and patterns that form the mechanism of discourse should be taught in the classroom .

His criticism of the term " communication strategies " , in part, arises from Faerch \& Kasper ' s (1983) taxonomy and limits to their conceptualization. Faerch \& Kasper (1983: 18), for example, theorized that the speaker in a communication event begins with a goal. This goal can be related to the speech act.

\section{4- Communication and Learning Strategies}

Over the past two decades, there has been an ever - growing interest in the study of language learning strategies (LLS) in the field of second language acquisition and communication in the foreign language. The ability of learners to apply learning strategies to different learning contexts aiming to seek ways to help students become more successful and autonomous in their efforts to learning contexts has been viewed as a major watershed in describing efficient learners, the results of that movement away from teaching and toward learning has created a plethora of terminology difficult and elusive for both practitioners and researchers. The moving target syndrome has been described by Oxford and Cohen (1992:13), as a category definition in this field tend to be dependent on " the inclination or epistemological understanding of the researchers ". Although some agreement has been reached, numerous questions have got to be answered .

Among the many elusive issues in LLS research, one of the most noteworthy is the relationship between communication and learning strategies. Researchers are concerned about whether strategies can contribute directly to language learning or not. Rubin (1987:25) proposed that compared with cognitive and metacognitive learning strategies, communication strategies are less directly related since "their main focus is on the process of participating in a conversation and getting meaning across or clarifying what the speaker intended ". Oxford (1990) later gave this direct - indirect distinction a more precise definition: the division line is whether the target language itself is directly or indirectly involved in the use of a given strategy - the mental processing of the L2.

\section{5- The Test}

To ascertain what compensation strategies EFL learners most utilized, least utilized, and the relationship between strategies, test score, sex, and age, a checklist of anticipated strategies were developed based on Oxford's list of compensation strategies. This checklist was included on an oral exam grading form:-

1) Tunes out, gives up

2) Abandons communication mid-utterance

3) Limits responses

4) Wrong guesses 
5) Requests more information

6) Seeks confirmation of understanding

7) Checks possibilities

8) "What did you say?" or equivalent

9) Uses mime or gestures

10) Switches to Arabic

11) Selects topics

12) Coins words

13) Uses circumlocution

14) Uses synonyms or antonyms

15) Uses metaphors, stories, experiences

The checklist was designed to facilitate fast recording of observable compensation strategies to coincide with the oral exam interview. Students were not graded on their use of compensation strategies. The test was merely seen as an opportunity to observe student compensation strategies when they might be most motivated to resort to them. Resource limitation and time constraints made it unfeasible to address the issue of unobservable compensation strategies in this study. In addition, audio and video were not utilized, but would have been useful additions. Strategies were detected and identified in a manner which allows observing compensation strategies used by EFL learners.

\section{6 - Procedures}

1. As participants engaged in conversation for the exam interview, the researcher checked observed compensations where appropriate on the checklist.

2. When compensation strategies were observed that had not been anticipated, they were written in a space reserved for other strategies and check marks indicated how many times they were utilized by students.

3. Information about the student age and gender was also recorded.

4. The data from the checklist was then inputted and subjected to statistical analyses. The statistical package SPSS, version 5.0.1 for Windows, was used to produce the results for usage: frequencies, percentages (\%), and correlations (r).

\section{7- Participant Composition}




\section{University of Thi-Qar Journal Vol.11 No.1 Mar 2016}

Web Site: https://jutq.utq.edu.iq/index.php/main Email: journal@jutq.utq.edu.iq

Participants included 72 4th year students at English department collage of education, ThiQar university. Their levels ranged from beginner to intermediate. They were 56 females and 16 males. Ages ranged from 18 to 40 , with $75 \%$ of the participants aged 18 to 26 . The mean age was 24.17 with a standard deviation of 3.93 .

\section{8- Total Uses of Each Strategy Observed}

Some strategies were not observed at all. Others were only observed once or twice. Table 1 lists strategies observed, the total number of times the strategy was employed by students, and the number of students who utilized the strategy

\section{Table 1}

List of Anticipated Strategies and Frequency of Usage

\begin{tabular}{|l|l|l|}
\hline Anticipated Students Compensation Strategy & $\begin{array}{l}\text { Number of Students } \\
\text { Employing Strategy }\end{array}$ & Occurrences \\
\hline Tunes out, gives up & 42 & 91 \\
\hline Abandons communication mid-utterance & 20 & 27 \\
\hline Wrong guesses & 54 & 105 \\
\hline Requests more information & 43 & 101 \\
\hline "What did you say?" or equivalent & 57 & 121 \\
\hline Uses Mime or Gestures & 12 & 20 \\
\hline Switches to Arabic & 40 & 37 \\
\hline Selects Topics & 2 & 3 \\
\hline Coins Words & 2 & 3 \\
\hline Uses circumlocution & 46 & 5 \\
\hline Uses synonyms or antonyms & 1 & \\
\hline
\end{tabular}




\section{University of Thi-Qar Journal Vol.11 No.1 Mar 2016}

Web Site: https://jutq.utq.edu.iq/index.php/main Email: journal@jutq.utq.edu.iq

This list demonstrates that asking for a repetition of the question was the most common strategy that participants utilized. Guessing and asking for more information were the next two strategies employed. Giving up was the next most used strategy, followed by switching to Arabic. A small number of students used other strategies, but these were much less frequently observed.

Table 2

Unanticipated Strategies and Frequency of Usage

\begin{tabular}{|l|c|c|}
\hline Unanticipated Compensation Strategies & Number of Student & Occurrences \\
\hline Repeats words not known & Employing Strategy & $\mathbf{3}$ \\
\hline Repeats questions & $\mathbf{2}$ & $\mathbf{1 9}$ \\
\hline Silently indicates need for assistance & $\mathbf{2}$ & $\mathbf{6}$ \\
\hline Says, "I don't understand." & $\mathbf{3}$ & $\mathbf{4}$ \\
\hline Pre-practices response & $\mathbf{4}$ & $\mathbf{8}$ \\
\hline Delay tactics & $\mathbf{8}$ & $\mathbf{1 5}$ \\
\hline Writing-spelling words & $\mathbf{1}$ & \\
\hline
\end{tabular}

\section{9- Unanticipated Strategies}

Several strategies were observed that had not been anticipated. Amongst these, the repetition of questions prior to responding was the most common, with 19 occurrences. Various types of delay tactics were also employed in 15 instances. Four students were observed on 8 occasions prepracticing their responses, usually in a low voice but nevertheless audible. On six occasions students made an obvious plea for assistance, but silently, without words. Three instances of students repeating a single word that was unknown were also observed. Finally, one student wrote out responses twice before speaking. Table 2 lists the unanticipated strategies, number of observations of their use, and the number of students who employed the strategy.

\section{0- Aggregated Categories}

To facilitate better results using the SSPS statistical package because of many occurrences of 0 observations, some strategies were combined. For example, "Tunes out, gives up" and "Abandons communication mid-utterance" were combined into a variable called "Reduction 


\section{University of Thi-Qar Journal Vol.11 No.1 Mar 2016}

Web Site: https://jutq.utq.edu.iq/index.php/main Email: journal@jutq.utq.edu.iq

Strategies", "Requests more information," and "What did you say?" were combined into "Seeks Help" "Wrong guesses," which indicates the strategy of guessing, and "Switches to Arabic ," were not combined with any other strategy. All the remaining strategies were combined into a category called, "Combined Other"

\section{1- Most and Least Frequent Compensation Strategies}

To answer the question, what strategy is most often employed by students in this study, frequencies of use of the strategy, at least once and once or more times, were compared. Table 3 below presents the results. 13 Students $(18.1 \%)$ used the strategy of seeking help one time. 61 students $(84.7 \%)$ employed the strategy one or more times, making this strategy the most utilized. 23 Students (31.9\%) utilized the strategy of guessing at least one time, while 54 students (75\%) were observed guessing one or more times. 18 Students $(25 \%)$ utilized the reduction strategies of giving up or tuning out at least one time, while 50 students $(69.4 \%)$ were observed using reduction strategies at least one or more times. 18 Students (25\%) were also observed switching to Arabic once, while 40 students (55.6\%). switched to Arabic one or more times. Finally, 16 Students (22.2\%) were observed using other strategies one time, while 25 students (34.7\%) were observed utilizing other strategies one or more times.

Table 3

Rank Order of Compensation Strategies Utilized by Study Participants, Most to Least

\begin{tabular}{|c|r|r|r|r|}
\hline Strategy & Once or More One observation & Once or Less & Zero observatic \\
\hline Seek Help & $61(84.7 \%)$ & $13(18.1 \%)$ & $24(33.3 \%)$ & $11(15.3 \%)$ \\
\hline Guesses & $54(75.0 \%)$ & $23(31.9 \%)$ & $41(56.9 \%)$ & $18(25.0 \%)$ \\
\hline Reduction & $50(69.4 \%)$ & $18(25.0 \%)$ & $40(55.6 \%)$ & $22(30.6 \%)$ \\
\hline Switch to Arabic & $40(55.6 \%)$ & $18(25.0 \%)$ & $50(69.4 \%)$ & $32(44.4 \%)$ \\
\hline Combined Other & $25(34.7 \%)$ & $16(22.2 \%)$ & $63(87.5 \%)$ & $47(65.3 \%)$ \\
\hline
\end{tabular}

Value $=$ number of participants observed not using or using the strategy.

Percentages $=$ the percent within each category compared to other frequencies for the same strategy.

These results indicate that students most often utilize the strategy of seeking help-asking for confirmation or more information - compared to the other strategies listed. Making guesses was 


\section{University of Thi-Qar Journal Vol.11 No.1 Mar 2016 \\ Web Site: https://jutq.utq.edu.iq/index.php/main Email: journal@jutq.utq.edu.iq}

the second most often observed strategy. A range of other strategies, such as using gestures and mime, synonyms and antonyms, coining words, circumlocutions, etc., as a combined category were the least observed strategy utilized.

Table 3, second and third columns, present the number of cases where the strategy was not utilized by any students and where it was only utilized once or less. The order of the strategies remains the same, but now less ambiguously. 11 Students $(15.3 \%)$ did not utilize the strategy of seeking help, while 24 students $(33.3 \%)$ used this strategy one time or less. 18 Students (25\%) made no observable guesses, while 41 students (56.9\%) made one or less. 22 Students (30.6\%) did not utilize any reduction strategies, while 40 students $(55.6 \%)$ utilized them one time or less. 32 Students (44.4\%) did not switch to Arabic during the test, while 50 students (69.4\%) switched to Arabic once or less. The combined other strategies were not utilized at all by 47 students $(65.3 \%)$, while 63 students $(87.5 \%)$ utilized them once or less.

These results demonstrate that the combined strategies-such as using synonyms, coining words, gesturing and using circumlocutions- are the least utilized. Switching to Arabic is the next least utilized strategy, then employing reduction Strategies, then Guessing, and finally, Seeking Help.

\section{2-Correlation Results}

To answer the question of whether there were any relationships between the uses of strategies and student success, the data was analyzed for Pearson Correlation Coefficients. Table 4 presents the results of correlations between strategies and test score. No relationships reached a significance greater than .05 , except for a negative relationship between test score and use of reduction strategies (Correlation Coefficient is -.5608). That is, the more students used reduction strategies, the lower their test score. This relationship, however, is not very surprising, because one would expect that a student who gives up and tunes out would likely not perform well on the test.

\begin{tabular}{|l|r|r|r|r|r|r|}
\hline & Exam & $\begin{array}{r}\text { Switches } \\
\text { Score }\end{array}$ & Guesses & Reduction & Seeks Help & Combined \\
\hline Combined & & & & & & 1.0000 \\
\hline Seeks Help & & & & & 1.0000 & .1354 \\
\hline Reduction & & & & & & \\
\end{tabular}


University of Thi-Qar Journal Vol.11 No.1 Mar 2016

Web Site: https://jutq.utq.edu.iq/index.php/main Email: journal@jutq.utq.edu.iq

\begin{tabular}{|l|c|c|c|c|c|c|}
\hline Guesses & & & 1.0000 & .1270 & .0835 & .1317 \\
\hline Switches To & & 1.0000 & .0888 & .1243 & .1190 & .2193 \\
\hline Arabic & & & & & & \\
\hline Exam Score & 1.0000 & .1284 & -.0732 & .5608 & .1756 & .1307 \\
\hline
\end{tabular}

\section{Table 4 :}

Aggregated Strategies Correlated With Exam Score

To answer the question of whether gender or age has a relationship with compensation strategy use, these items were also analyzed for Pearson Correlation Coefficients. Table 5 presents the results.

\section{Table 5}

Correlations of Strategies with Gender \& Age

\begin{tabular}{|l|c|c|}
\hline & Age & Gender \\
\hline Combined Other & .0708 & .2025 \\
\hline Seeks Help & .1050 & .0016 \\
\hline Reduction & .1136 & .0449 \\
\hline Guesses & .2729 & .2927 \\
\hline Switches To Arabic & .0287 & .0084 \\
\hline Exam Score & .0482 & .0053 \\
\hline
\end{tabular}

This table shows that only two correlations reach a significance below the .05 level, guessing and gender, as well as guessing and age. The correlation between gender and age shows that female students had a tendency to guess incorrectly more than males, which may mean that they have a tendency to guess more than males. The correlation between age and guessing shows that the older a person is, the more likely they were to employ the guessing strategy (again, incorrectly). No other relationships reached a level of significance.

\section{3- Discussion}




\section{University of Thi-Qar Journal Vol.11 No.1 Mar 2016 \\ Web Site: https://jutq.utq.edu.iq/index.php/main Email: journal@jutq.utq.edu.iq}

In the process of conducting this study, several limitations emerged. The first and most problematical stems from the fact that not all compensation strategies are observable. For example, guessing correctly would be difficult to detect unless students somehow indicated each time they were guessing. To circumvent this difficulty, wrong guesses were used to indicate the strategy of guessing. However, when a student states an inappropriate response, it is difficult to ascertain whether the student guessed incorrectly or misunderstood a question. In this study, such responses were always recorded as guesses. Further, the absence of audio or video recordings limits the potential for observing compensation strategies and the dynamics related to their employment. Nevertheless, this study adds empirical data to the literature on this topic.

Khanji (1996: 150 ), in his study found that students at a low level were most likely to adopt repetition strategies, as a form of delay tactic. Such a strategy was not observed to be very common among students in this study. Khanji (1996) also found message abandonment strategies(herein called reduction strategies) to be the second most commonly utilized by low level students. In this study, the most utilized and second most utilized strategies were found to be seeking help and guessing, respectively, then followed by reduction strategies. Interestingly, Khanji (1996:153) found EFL learners to be least inclined to employ the strategy of appealing for assistance, whereas students were found to employ this strategy the most. This gap is not related to terminology differences. Khanji (1996:148) recorded appeal for assistance when students asked for help in English from their interlocutors or from the teacher. In the current study, the same standard was used. One explanation for the difference might be student exposure during class sessions to encouragement to use appeals for assistance to help maintain the conversation flow.

The high tendency of students to resort to reduction strategies, however, greatly inhibits the conversation flow, but these strategies have a positive function as well. Oxford (1990:84 ), for example, reported that they serve to "emotionally protect the learner" and make the interlocutor slow down, stop, or change gears, giving the learner a chance to catch up. Teachers can also utilize these breakdowns for identifying areas that require more instruction and practice. Students can also be taught to use these breakdowns as an opportunity to identify what they need to learn. Embarrassment over the breakdown can be transformed to empowerment that directs students to focus on the language areas most relevant to what they want to communicate. One cause for student utilization of reduction strategies might be anxiety about accuracy. Many low level students mistakenly believe that there is always a one-to-one correspondence between first and second language. This mistaken idea causes panic when the exact correct word is unavailable. In addition, preoccupation with accuracy of grammar or pronunciation might lead to frustration and breakdown. Due to the fact that reduction strategies are likely to negatively impact student oral exam scores and conversational experiences, understanding the causes for students resorting to these strategies can help teachers build student skills for alternative strategy utilization. Guiding students to use alternative strategies is an important task for teachers. This study demonstrates that students utilize relatively few compensation strategies. Introducing new strategies to students can help expand their repertoire and improve their communicative competence, creating greater satisfaction, higher motivation, and other positive consequences cited above. 


\section{University of Thi-Qar Journal Vol.11 No.1 Mar 2016 \\ Web Site: https://jutq.utq.edu.iq/index.php/main Email: journal@jutq.utq.edu.iq}

\section{Conclusions :-}

This study set out to identify compensation strategies that students most utilized and least utilized, as well as to look at the relationships between strategies and test scores, gender, and age. Participants in this study were found to most employ help seeking, compensation strategies and to least employ a combination of strategies that included using circumlocutions, coining words, and gesturing. This information can help teachers identify potential new strategies to explore and utilize.

Further, a high number of study participants employed reduction strategies- giving up, tuning out or abandoning the message in mid-utterance. Such strategies may be culturally motivated or beneficial for emotional reasons, but they often inhibit communication, reduce practice opportunities, promote a sense of inability, and negatively impact test scores. Therefore, teachers should seek to help students resort less to reduction strategies less and more often to alternative compensation approaches.

In addition, It is noticed that there is noticeable deviance from native speaker norm in the interlanguage syntax, word choice or discourse pattern, apparent, obvious desire on the part of the speaker to communicate 'meaning' to listeners as indicated by overt and covert discourse clues, there is also evident and sometimes repetitive attempts to seek alternative ways, including repairs and appeals, to communicate and negotiate meaning. There is also overt pausological, hesitational and other temporal features in the speaker's communicative behavior, also it is noted that there is a presence of paralinguistic and kinesic features both in instead of and in support of linguistic inadequacy.

\section{References}

Abdesslem, H. (1996). Communication Strategies or Discourse Strategies in Foreign Language Performance. International Review of Applied Linguistics in Language Teaching, Sheffield uk. 34(1), 49-62.

Bandura, A. (1997). Self-efficacy: The exercise of control. New York: Freeman

Brown, H. (1994). Principles of language learning and teaching (3rd ed.). Englewood Cliffs, NJ: Prentice-Hall.

Faerch, K., \& Kasper, G. (1983). Plans and Strategies in Foreign Language Communication. London: Longman.

Gardner, R. C. (1985). Social psychology and second language learning: the role of attitudes and motivation. London: Edward Arnold.

Khanji, R. (1996). Two Perspectives in Analyzing Communication Strategies. International Review of Applied Linguistics in Language Teaching, 34(2), 144-155.

Kim, D. D. I., \& Margolis, D. P. EFL students' exposure to English listening and speaking: instruction, multimedia, travel experience, and motivation. TESOL Journal, 3. 


\section{University of Thi-Qar Journal Vol.11 No.1 Mar 2016}

Web Site: https://jutq.utq.edu.iq/index.php/main Email: journal@jutq.utq.edu.iq

Lewis ,M. (1999) . How to study foreign Language .London : Macmillan press LID.

Oxford, R. L. (1990). Language learning strategies that every teacher should know. Boston: Heinle \& Heinle Publishers.

Rubin, J. (1987). Learner strategies: Theoretical assumptions, research history and typology. In A. L. Wenden \& J. Rubin (Eds.) Learner strategies in language learning (pp. 15-30). Englewood Cliffs, NJ: Prentice Hall.

Windle, S. (2000). From Confusing to Confucian: Towards an Understanding. The English Connection, 4(6), 1, 6-8. 